\title{
COVID-19 y tomografía
}

\section{COVID-19 and chest CT-scan findings}

David Loja-Oropeza ${ }^{1, a}$, Maricela Vilca-Vásquez ${ }^{2, b}$, Bruno Loja-Vilca ${ }^{3, c}$
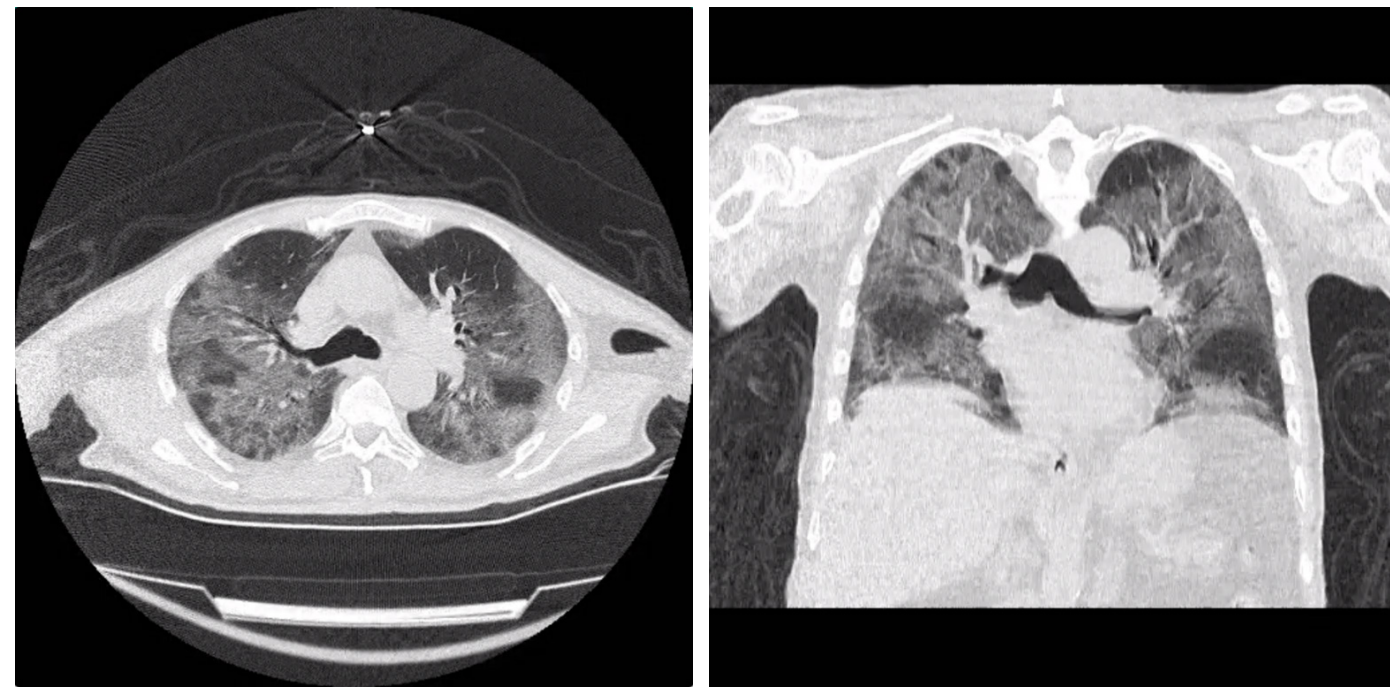

Varón de 73 años, diabético. Acudió con historia de siete días con fiebre, tos, y cansancio al caminar. En el primer día la prueba rápida fue no reactiva. Al cuarto día presentó polipnea y saturación de $\mathrm{O}_{2}$ en $85 \%$. La Tomografía de tórax mostró: Opacidades en vidrio deslustrado multilobar a predominio periférico en ambos pulmones. No había broncograma aéreo; se concluyó que las lesiones extensas en ambos pulmones eran sugerentes de COVID 19. CO-RADS 5. Recibió ceftriaxona, enoxaparina, dexametasona y oxígeno por máscara de reservorio. Estuvo hospitalizado tres semanas, la evolución fue favorable saliendo de alta. La tomografía está indicada en pacientes con COVID-19 y deterioro clínico y en un medio de recursos limitados, para estratificar pacientes con sospecha de COVID-19 que presenten clínica moderada-severa y alta probabilidad pre-test de tener la enfermedad. No está indicada en pacientes con sospecha de COVID-19 y clínica leve. La TEM de tórax permite distinguir la COVID 19 de la neumonía viral con una precisión de moderada a alta; Sensibilidad 97\% y Especificidad 25\%; VPP 92\% y VPN de $42 \%$.

A 73-year-old male diabetic patient was admitted with a seven-day history of fevers, cough and dyspnea on exertion. A rapid test was negative on the first day of admission. On the fourth admission day the patient presented polypnea and oxygen saturation of $85 \%$. The chest CT-scan showed multilobe peripheral ground glass opacities,

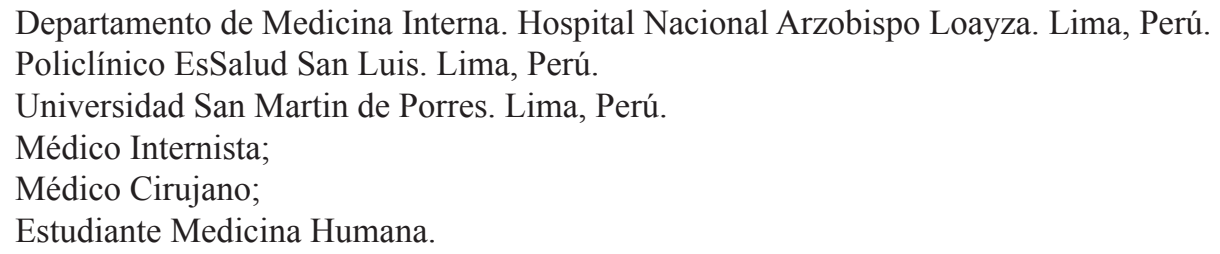


no air bronchogram was observed. These lesions were highly suggestive of COVID 19. CO-RADS 5. The patient received ceftriaxone, enoxaparin, dexamethasone and high flow oxygen. He was admitted for three weeks and then discharged. Chest CT-scan is indicated in COVID-19 patients with clinical worsening, in resource limited settings it helps stratifying patients with high suspicion and high pre-test probability. It is not indicated in patients with mild disease. The chest CT-scan allows to distinguish COVID-19 from other causes of viral pneumonia with a sensitivity of $97 \%, 25 \%$ specificity, PPV $92 \%$ and NPV of $42 \%$.

\section{Correspondencia:}

David Loja Oropeza

Reynolds 114-101 Lima 41, Perú

Teléfono: 997354120

Correo electrónico: davidloja@hotmail.com

https://www.instagram.com/drdavidlojaoropeza/ 